\title{
Development of the silver eel (Anguilla marmorata) gonad during downstream migration in the Lake Poso system, Central Sulawesi
}

\author{
Gadis Sri Haryani ${ }^{*}$, Triyanto ${ }^{1}$, Octavianto Samir ${ }^{1}$, Lukman $^{1}$, Hidayat ${ }^{1}$, Fauzan Ali ${ }^{1}$, \\ Fachmijany Sulawesty ${ }^{1}$, Hendro Wibowo ${ }^{1}$, Foni Agus Setiawan ${ }^{1}$, Endra Triwisesa ${ }^{1}$, \\ Mohammad Riyanto ${ }^{2}$, Angga Dwinovantyo ${ }^{3}$, Eva Nafisyah $^{1}$
}

${ }^{1}$ Research Center for Limnology, Indonesian Institute of Sciences (LIPI), Cibinong, Indonesia ${ }^{2}$ Faculty of Fisheries and Marine Sciences, IPB University, Indonesia, Bogor, Indonesia

${ }^{3}$ Research Center for Deep Sea, Indonesian Institute of Sciences (LIPI), Ambon, Indonesia

\begin{abstract}
The Lake Poso system is located in Central Sulawesi and is connected to the Tomini Bay by the Poso River. It is known that five out of nine Indonesian eel species were found at the Poso River. Anguilla marmorata is the most caught species. However, uncontrolled catching during downstream migration and the construction of a hydropower plant threaten the silver eel in the Lake Poso system. Research on silver eel $(A$. marmorata) in Lake Poso was conducted to determine and compare the condition of gonad development as part of the reproductive process. This represents essential information in eel fisheries management in Lake Poso. The eels were collected through bamboo traps (waya masapi). The present study calculates the GSI and HSI values, and histological analyses characterize the gonad. The GSI of eel ranges from 1.95 to $5.69 \%$, and the HSI value ranges from 0.83 to $1.16 \%$. Histological observation showed that eels from Tentena (Lake Poso outlet) and from the estuary of Poso River have ovaries in the early vitellogenic stage (III) and the vitellogenic stage (IV).
\end{abstract}

\section{Introduction}

Lake Poso is located in Central Sulawesi and is connected to the Tomini Bay by the Poso River. Lake Poso is one of Indonesia's 15 priority lakes that must be appropriately managed [1]. One of the essential natural resources of Lake Poso is the freshwater eel. Five of the nine (9) species of Indonesian freshwater eel are found at the mouth of Poso River: Anguilla marmorata, A. celebesensis, A. bicolor pacifica, A. interioris and, A. borneensis, of which A. marmorata is the most-caught species and has been traded for decades [2]. According to [3], Lake Poso is the habitat of A. marmorata, A. mauritania, and A.

\footnotetext{
* Corresponding author: gadis@limnologi.lipi.go.id
} 
celebesensis. The characteristics of the aquatic habitats of Sulawesi support the presence of A. marmorata [4].

In 1970, Lake Poso produced 22 tons of eel [5]. This figure increased to 41.5 tons in 1980 but dropped to 30.5 tons in 1998 [6]. In 2009, the eel catch was only 6.5 tons [7]. The potency number of adult eels decreased by 3,000 eels per year, from 9,000 eels to 6,000 eels [3].

Uncontrolled fishing during their downstream migration and the construction of a hydropower plant could threaten most of the Anguillid eel in the Lake Poso system. The fishing is threatening the silver eel population by local people, who use traps (Wayamasapilocal name) and Lake Poso's river mouth during the eel's downstream migration. This activity continues throughout the year. Another threat to the eel population is the hydroelectric power plant on the Poso River, which started operating in 2016. The construction of the hydropower plant down the Poso River poses yet another threat to the ever-decreasing population of eel because it prevents the silver eel from migrating downstream and the young eel from migrating upstream from the estuary to Lake Poso [8]. A. marmorata (Indonesia) include in the IUCN Red Lists of Threatened Species category.

Because of these problems, research was conducted on silver eel (A. marmorata) in Lake Poso to determine and compare the condition of gonad development as part of the reproductive process, which is the essential information for eel fisheries management in Lake Poso. eels carried out the reproduction aspects of the eels during the downstream spawning migration by investigating their gonads and liver. The study will compare this study to the previous studies carried out in 1998 [9], 2007 [10], and 2008 [11] to determine the impact of the hydro-plant construction on the condition of eel reproduction in Lake Poso.

\section{Methodology}

The eel sampling was conducted in Lake Poso and Poso River estuary in Mei and June 2021 (Fig. 1). The eels are caught in a bamboo trap (local name: waya masapi) (Fig. 2). All eels were identified morphologically, and the study measured the Body Weight (BW) and Total Length (TL). The weight of the gonads $(\mathrm{GW})$ and the livers (LW) were also recorded.

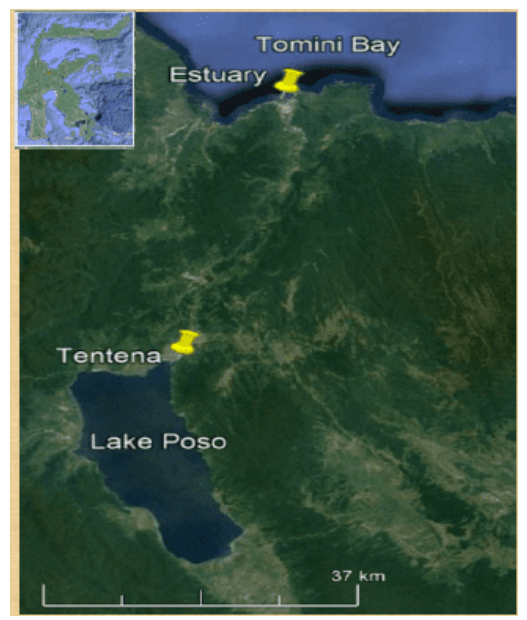

Fig. 1. Map of eel sampling locations in the Lake Poso (Tentena/Outlet Lake Poso and Estuary of Poso River) 


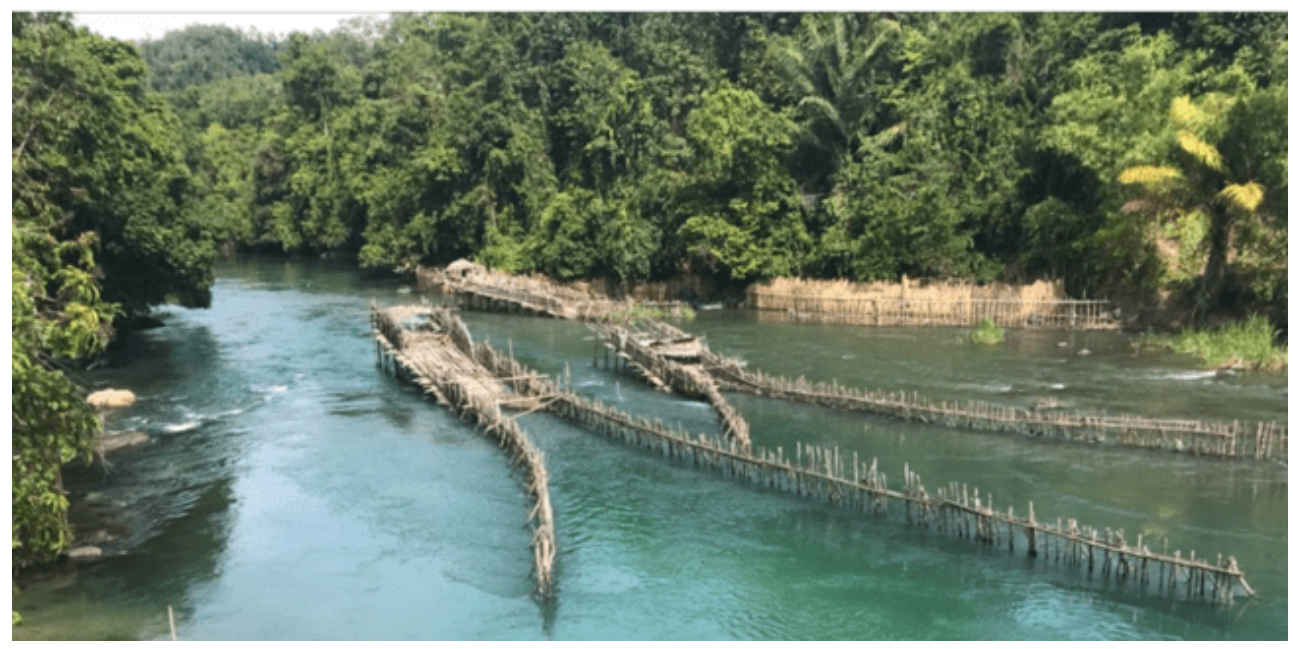

Fig. 2. Bamboo trap/fence (Waya Masapi)

The Gonad Somatic Index (GSI) was calculated as follows [12,13]:

GSI $=($ gonad weight/body weight $) \times 100 \%$

The Hepato Somatic Index (HSI) was calculated as follows:

$$
H S I=(\text { liver weight/body weight }) \times 100 \%
$$

For histological examination, fragments from both sides and the middle part of the gonads were fixed in $10 \%$ buffered formalin. The sectioned gonads that were 6 (six) $\mu \mathrm{m}$ thick were stained with Mayer's Haematoxylin and Eosin (HE). The maturation development stage of the gonad was defined by the development of oocytes, as follows (modified from [9] and [11]):

-Phase I: the presence of oogonia and primary oocyte development.

-Stage II: immature cells with strongly basophilic cytoplasm and primary oocytes with a few lipid vesicles.

-Stage III: oocytes early maturation stage with perinucleolar in nucleus and lipid vesicles in the cytoplasm.

-Stage IV: oocytes in vitellogenic stage with a nucleus and perinucleolar, lipid vesicles, vitellin globules in the periphery of cytoplasm.

-Stage V: mid-vitellogenic oocytes, nucleus, peripheral vitellin globules, zona radiata, and vacuolated cytoplasm.

-Stage VI: maturation, the nucleus dissolved, and ooplasm consists of yolk bodies.

\section{Result}

A total of seven silver eels (Anguilla marmorata) were caught from two study sites: Lake Poso and the estuary of Poso River, with body weight (BW) ranging from 2,390 to 5,610 g, and total length TL) ranging from $940-1,285 \mathrm{~cm}$ (Table 1). The smallest silver eel $(2,390 \mathrm{~g}$ 
in body weight and $940 \mathrm{~cm}$ in total length) was collected in May 2021, while the enormous silver eel (5,560 g; 128,5 cm) was organized in June 2021 (Fig. 3).

Table 1. Morphology and physiological indices of A. marmorata

\begin{tabular}{|c|c|c|c|c|}
\hline Parameter & $\begin{array}{c}2021 \\
\text { (Present study) }\end{array}$ & $2008^{10}$ & $2007^{9}$ & $1998^{8}$ \\
\hline Total Length (mm) & $940-1,285$ & $832-1,368$ & $460-1,060$ & $530-1,045$ \\
\hline Body Weight (g) & $2,390-5,610$ & - & $420-4,950$ & $900-6,500$ \\
\hline GSI (\%) & $1.95-5.69$ & $0.0-6.40$ & $0.06-4.40$ & $0.33-3.38$ \\
\hline HSI (\%) & $0.83-1.16$ & - & $0.63-1.97$ & $0.29-1.35$ \\
\hline Maturation Stage & III-IV & I - V & I - IV & I - IV \\
\hline Diameter oocyte (mm) & $0.065-0.197$ & - & $0.035-0.155$ & $0.03-0.140$ \\
\hline
\end{tabular}

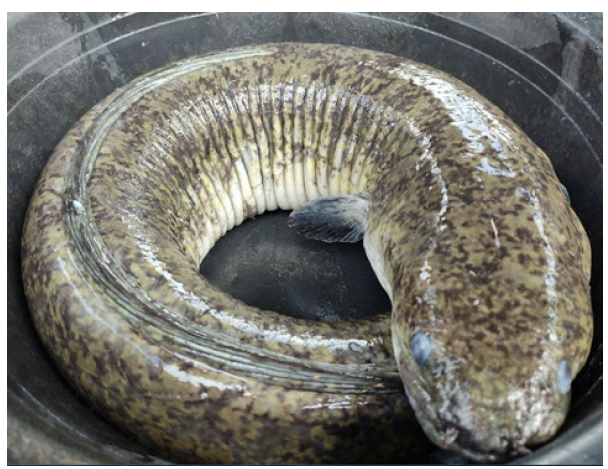

Fig. 3. Eel from Lake Poso

The gonad of eels paired pink lamellae that extend on the dorsal abdomen (Fig. 4). Gonadosomatic index (GSI) values of the silver eels range from 1.95 to $5.69 \%$. The lowest GSI value of $<2 \%$ was found only in one eel with low HSI $(<1 \%)$.

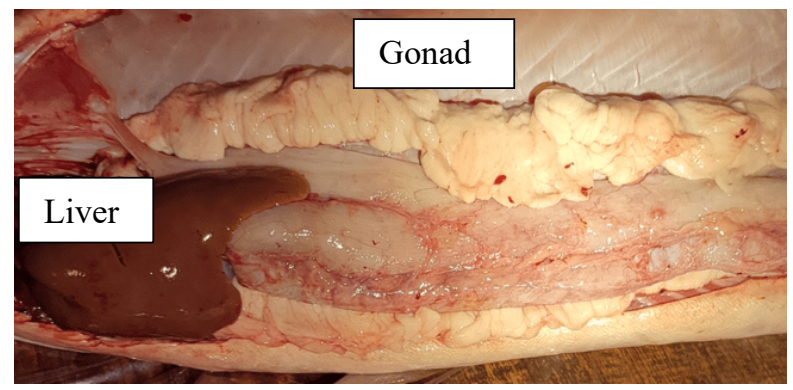

Fig. 4. The gonad and liver of eel

Hepatosomatic index (HSI) values of the silver eels range from 0.83 to $1.16 \%$, with the eel in the estuary having the highest HSI $(1.16 \%)$, revealing the active metabolism of the liver to produce vitellogenin during the downstream migration from lake to estuary.

The gonadal histology showed that oocyte of maturation stage III and IV. Stage III, or the early vitellogenic stage, involved the development of oocytes with perinucleolar in the nucleus and lipid vesicles in the cytoplasm of oocytes (Fig.5). Stage IV (vitellogenic stage) 
is characterized by vitellogenic oocytes, with a nucleus and perinucleolar, and the cytoplasm filled with lipid vesicles and peripheral yolk granules (Fig.6).

The diameter of oocytes in stage III (early vitellogenic) and IV (vitellogenic) ranged between $0.065-0.197 \mathrm{~mm}$ (Table 1). The eel caught in the estuary have oocytes in stage IV, and all eel caught in the Lake Poso outlet (Tentena) have gonad in stage III.

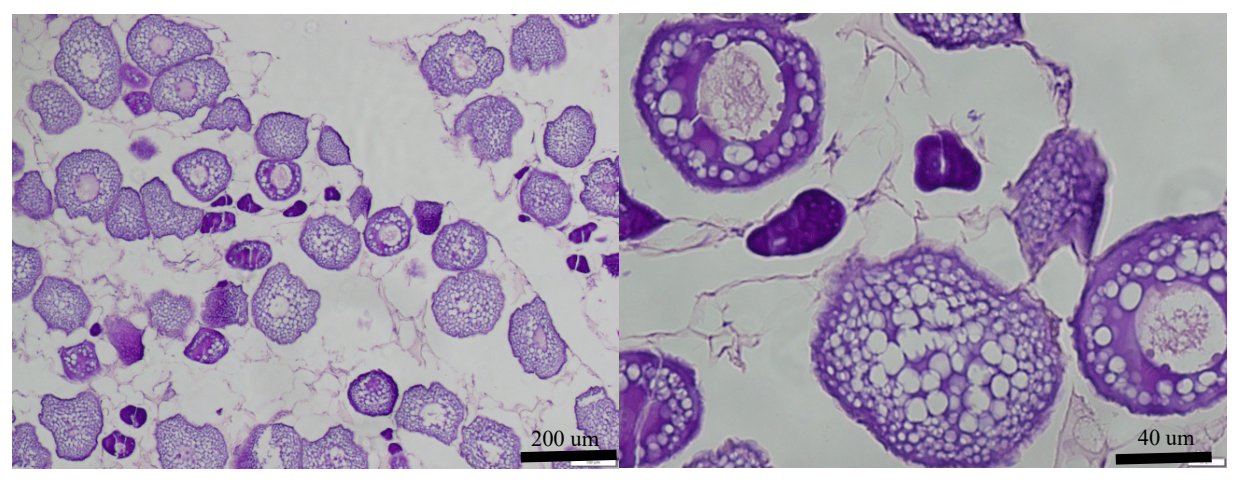

Fig. 5. Histological sections of gonadal tissue of Anguilla marmorata from Tentena with oocytes in early vitellogenic stage (stage III). Nucleus with Perinucleolar (black arrow). Lipid vesicles in the cytoplasm (red arrow).

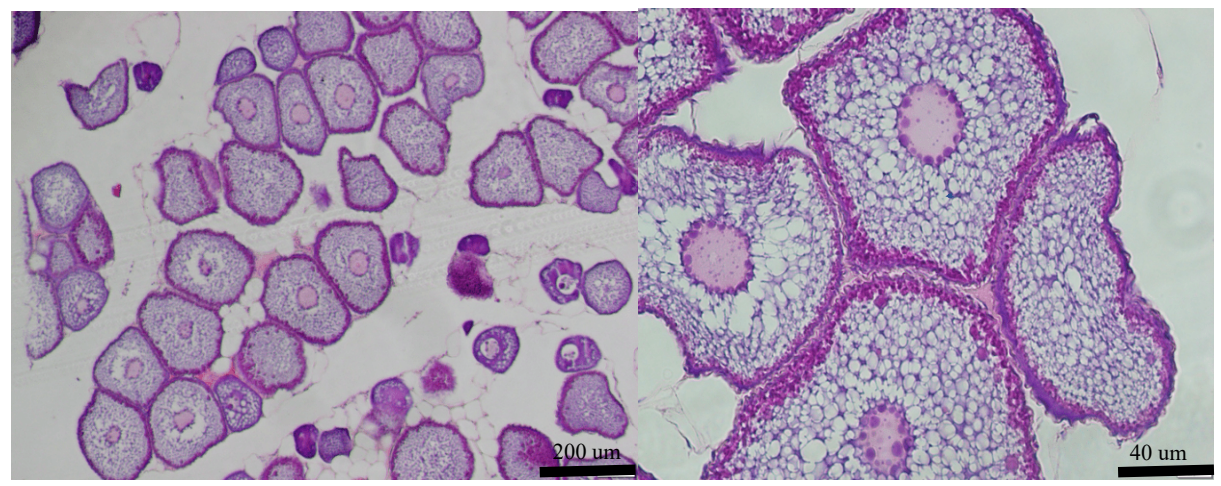

Fig. 6. Histological sections of gonadal tissue of Anguilla marmorata from the estuary, with oocytes in the vitellogenic stage (stage IV). Vitellin globules (black arrow) in the periphery of cytoplasm, lipid vesicles (white arrow), nucleus, and perinucleolar (thin arrow). 


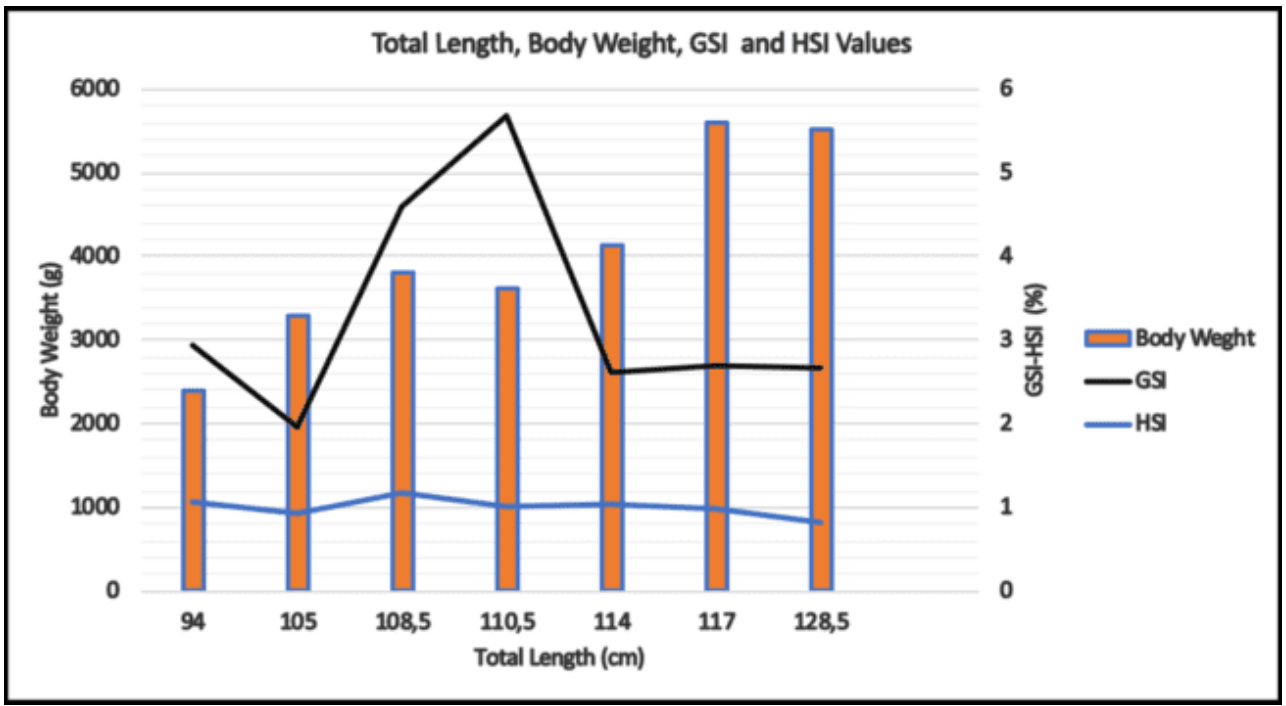

Fig. 7. Total length, Body Weight, GSI, and HSI values of $A$. Marmorata.

Fig. 7 showed variation of the body weight, GSI \& HSI values by total length distribution. It revealed that eel body weight tends to increase with an increase in total length. Eel with a total length of $110.5 \mathrm{~cm}$ had the highest GSI value, and the eel with a total length of 108.5 $\mathrm{cm}$ had the highest HSI value. The longest eel has the lowest HSI values. The HSI values were not always increased when the total length increased. It can be seen from eels with a total length of $114 \mathrm{~cm}$ to $128.5 \mathrm{~cm}$; the HSI values were still low $(<1 \%)$.

\section{Discussion}

All eels caught in Lake Poso and the Poso River estuary are A. marmorata. The eel $A$. marmorata is the most broadly distributed species from the southeast African coast to Asia and Polynesia [14]. In the other study (in preparation), we found a fisherman caught an eel in Lake Poso with $22.5 \mathrm{~kg}$ of body weight. According to Castle [15], A. marmorata can grow up to $2 \mathrm{~m}$ and $21 \mathrm{~kg}$.

A. marmorata with TL more than $70 \mathrm{~cm}$ were silver eels and had maturing gonads [8]. [14] found that $A$. marmorata caught in Tentena with TL $>50 \mathrm{~cm}$ were silver eel. The $A$. marmorata downstream migration is related to body size rather than age [14, 17]. Different from A. bicolor bicolor and A. bengalensis bengalensis, their maturation increased with the age of the eel [18].

In this study, we have not found any eel with immature gonads as those from previous studies. This finding is because the eels were caught in the Lake Poso outlet in the season of downstream migration. The downstream migration of silver eel occurs from January (rainy season) to August (o the beginning of the dry season), and only a few were observed from August (end of the dry season) to December (the rainy season) [2, 16, 19].

The GSI values of eels are lower than the GSI values found in 2008 [10], where all $A$. marmorata from Lake Poso had GSI values greater than 4.0 (6.4 in maximum value). But those from eels in 1998 [8] and 2007 [9] were lower than the GSI values from the present study. Positive correlations were found between GSI and maturation stages [20].

All eels from Lake Poso had a healthy, large, and bright red liver. This liver condition was similar to Japanese eels [21]. According to Ng \& Idler [22], the liver is very active in producing vitellogenin in oocytes formation. Compared to previous studies (1998 and 
2007), the HSI values from the present study are relatively lower. This condition corresponds to the GSI values, which were lower than the GSI from eels in 2008.

The more giant eels (in length and weight) do have not the GSI and HSI values higher than smaller eels. This result differed from eels from Segara Anakan, where the HSI values trend increased by the length [23]. The more enormous eels from Poso still have developing gonads during their migration to freshwater. The next stage of gonad maturation and the spawning will happen in the sea in high salinity (>30 ppt) [24, 25].

All oocytes in gonads have a diameter of $>0.10 \mathrm{~mm}$ categories for sexually maturing adults [26]. According to this statement, it is clear that most silver eels in Lake Poso and the estuary are sexually maturing adults, with vitellogenic oocytes that have a diameter of $>$ $0.10 \mathrm{~mm}$. The diameters of oocytes in the vitellogenic stage in this study were more significant than the oocytes from previous studies. But the maturation stage of eel in the previous study (2008 [11]) was more advanced (stage V, mid-vitellogenesis) than those of the present study, which was in stage IV. Oocyte diameters of eels caught in the estuary are slightly bigger than those from eels in Lake Poso. The oocyte development of eels from the estuary is by the highest HSI values. It seems that the eels in the estuary have relatively more developed gonads compared to eels in the Lake Poso outlet, with high GSI values.

Although silver eel A. marmorata was found in the estuary, it isn't easy. It needs more detailed data to predict whether the eels from Lake Poso can migrate through the dam in the middle part of the Poso river. Future studies should investigate the origin of silver eels in the estuary, for example, by using tagging methods. This information is essential for predicting the efficiency of eel ladder construction in the upper part of the dam. Migration of adult eel through hydropower dam turbines also causes mortality [27], as a silver eel in the Poso system. We should consider this problem to protect eel population in Lake Poso.

To protect eel resources, the Ministry of Marine Affairs and Fisheries of the Republic of Indonesia issued a regulation (No.80/2020) regarding the limited protection of Eel Fish (Anguilla spp). In this regulation, adult $A$. marmorata and $A$. celebesensis weighing more than five (5) kilograms may not be caught at all times. In the present study, several eels have a bodyweight of fewer than five kilograms, and there was even an eel with $2.3 \mathrm{~kg}$ body weight, and all eels were silver eels. We suggest that the regulation should be considered from this finding to protect more the silver eel and give it more opportunities to migrate downstream and spawn in the open sea.

\section{Conclusion}

A total of seven silver eels ( $A$. marmorata) with the TL ranging from 940 to 1,285 mm, and body weight ranging from 2,390 to $5,610 \mathrm{~g}$ has early vitellogenic (stage III) and vitellogenic stage (stage IV) of gonad maturation. Eels in the Poso River estuary and Lake Poso outlet showed metabolism activities with relatively high HSI and GSI values. The conditions of gonad development were similar to previous studies. It seems that artificial habitat change and fishing activities have not influenced the eel's gonad development.

\section{Acknowledgement}

The authors would like to thank the Ministry of Finance of the Republic of Indonesia through the LPDP RISPRO INVITASI program 2020 to fund this research activity. The authors are grateful to Ms. Lian Gogali and Mr. Kurniawan from Institut Mosintuwu-Poso, fisherman of eel in Lake Poso, Central Sulawesi, and all parties involved and participated in conducting the research. 
Contributorship: Gadis Sri Haryani, Triyanto, Octavianto Samir are the main contributors to this paper. All other authors contributed equally to this publication.

\section{References}

1. Ministry of Environment and Forestry, Republic of Indonesia. The Grand Design of Indonesian Lake Conservation and Rehabilitation (Ministry of Environment and Forestry, Indonesia, 2015)

2. H. G. Sugeha., J. Aoyama, K. Tsukamoto, Limnotek, 13, 1 (2006)

3. Krismono, E. S. Kartamihardja, J. Kebijakan Perikanan Indonesia, 4, 1 (2012)

4. Amrullah, E. Rosyida, Ardiansyah, Hartinah, Wahidah, AACL Bioflux, 12, 5 (2019)

5. G. S. Haryani, Lukman, P. E. Hehanussa, Prosiding Forum Perairan Umum Indonesia XIII (BPPPU, Cianjur, Jawa Barat, 2003)

6. Husnah, W. H. Tjahjo, A. Nastiti, Sulistiono. Status Keanekaragaman Hayati Sumberdaya Perikanan Perairan Umum di Sulawesi (BRPPUPP, Palembang, 2010)

7. Dinas Perikanan Kabupaten Poso, Fisheries Data of Poso Regency (Unpublished Report, 2009)

8. M. R. Mamondol. Simposium Asosiasi Teolog Indonesia (ATI) Regional Sulawesi (Poso, Sulawesi Tengah, 2018)

9. G. S. Haryani, Limnotek, 5, 1 (1998)

10. G. S. Haryani, Lukman, Triyanto, J. Iktiol. Ind., 8, 1 (2008)

11. T. Arai, Ecol. Evol. 4 (2014)

12. G. Delahunty, V. L. De Vlaming, J. Fish Biol., 16 (1980)

13. M. Htun-Han, J. Fish Biol., 13 (1978)

14. R. Wakiya, H. Itakura, K. Kaifu, Zool Stud, 58, 34 (2019)

15. P. H. J. Castle. Anguillidae. In: Daget J, Grosse JP, Thys's van den Audenaerde DFE (eds) Checklist of the freshwater fishes of Africa (ORSTOM, Bruxelles, 1984)

16. Krismono, M. R. A. Putri, J. Lit. Perikan. Ind. 18, 2 (2012)

17. J. Aoyama, Miller, M. J. The silver eel. In Eel Biology (Springer, Tokyo, 2003)

18. I. J. Chai, T. Arai, J. App. Animal Res. 46, 1 (2018)

19. G. S. Haryani, P. E. Hehanussa, Rep. Suwa Hydrobiol, 12 (2000)

20. T. Arai, S. R. Abdul Kadir, Sci. Rep. 7, 41649 (2017)

21. K. Tsukamoto, S. Chow, T. Otake, H. Kurogi, N. Mochioka, M. J. Miller, J. Aoyama, S. Kimura, S. Watanabe, T. Yoshinoga, A. Shinoda, M. Kuroki, M. Oya, T. Watanabe, K. Hata, S. Ijiri, Y. Kazeto, K. Nomura, H. Tanaka, Nature Communications, 2, 179 (2011)

22. T. B Ng., D. R. Idler. Fish. Physiology, 9 (1983)

23. I. Herianti, D. Nugroho, Bawal, 3, 3 (2010)

24. F. W. Tesch. The Eel, biology and management of Anguillid eels (Chapman and Hall Ltd, London, 1977)

25. B. Querat, J. L. Hatey, A. Hardy, Proceeding of the International Symposium on Reproductive Physiology of Fish, Wageningen (1982)

26. N. W. Pankhurst, J. Fish. Biol., 21 (1982)

27. C. R. Liermann, C. Nilsson, J. Robertson, R. Y. Ng, Bio Science 62, 6 (2012) 